Original Article

\title{
PHYTOCHEMICAL SCREENING, ANTIOXIDANT AND ANTIMICROBIAL ASSESSMENT OF PLUCHEA INDICA (L.) LESS EXTRACT AS AN ACTIVE INGREDIENT IN NATURAL LOTION BAR
}

\author{
SIRIKHWAN TINRAT ${ }^{*}$ \\ 1Department of Biotechnology, Faculty of Applied Science, King Mongkut's University of Technology North Bangkok, Bangkok 10800, \\ Thailand \\ Email: sirikhwan.t@sci.kmutnb.ac.th \\ Received: 06 Nov 2020, Revised and Accepted: 09 Jan 2021
}

ABSTRACT

Objective: To screen phytochemical compounds and study antioxidant and antimicrobial activities of Pluchea indica (L.) Less (PI) leaves extracts for assessment the moisturizing lotion bar formulation containing it's as a bioactive ingredient.

Methods: PI leaves were extracted in different solvents. Crude extracts were screened phytochemical compounds and evaluated antioxidant and antimicrobial activities before formulating to antibacterial moisturizing lotion bar.

Results: $95 \%$ ethanolic extract displayed high antioxidant activities. DPPH radical scavenging capacity with $\mathrm{IC}_{50}$ was $6.80 \pm 0.04 \mu \mathrm{g} / \mathrm{ml}$ $(61.37 \pm 0.41 \%)$ and the ferric reducing ability power was $381.20 \pm 0.10 \mathrm{mg} \mathrm{AAE} / 100 \mathrm{gDW}$. Additionally, $95 \%$ ethanolic extract served as a broad spectrum bacteriostatic agents against gram-positive and gram-negative species with an inhibition zone of $6.50 \pm 0.00-46.67 \pm 0.58$ mm. It also was simultaneously as a broad spectrum bactericidal agents (MIC and MBC value of $25-200 \mathrm{mg} / \mathrm{ml}$ ) by broth micro-dilution method. The screened phytochemical constituents (saponins, tannins, flavonoids, terpenoids, steroids, and alkaloids) in PI leaves extract may be responsible for high biological activities. Thus, 95\% ethanolic extract was the most appropriate bioactive ingredient for formulated the product development.

Conclusion: The developed moisturizing lotion bar with $0.0041 \%$ of $95 \%$ ethanolic extract was the most eligible formula that showed good appearance, odor, color, homogeneity, after feel and stability. This extract-containing lotion bar formulation achieved a high level of customer satisfaction by sensory evaluation and development of this specific formulation should be subject to further clinical investigation.

Keywords: Pluchea indica, Phytochemical compounds, Antioxidant and antimicrobial activities, Extraction solvents, Natural lotion bar

(C) 2021 The Authors. Published by Innovare Academic Sciences Pvt Ltd. This is an open access article under the CC BY license (https://creativecommons.org/licenses/by/4.0/) DOI: https://dx.doi.org/10.22159/ijcpr.2021v13i2.41555. Journal homepage: https://innovareacademics.in/journals/index.php/ijcpr

\section{INTRODUCTION}

Nowadays, many people's behaviors in all genders and ages are paying more attention to their skincare. Skin is the external organ of human that is most exposed to the various foreign matters in the diverse environment, which may cause various skin-related disorders [1]. In order to prevent skin disorders, it is always necessary to well protect keep and maintain your skin. There are a wide variety of popular skincare products available today, such as moisturizing, anti-aging, sunscreen and skin whitening products in term of lotions and creams. Skincare products that have been currently very popular are natural lotion products. Because it can reduce the side effects or skin irritation symptoms of consumers. The herbal trend has now received a leapfrogging interest. As a result, there are continuing efforts to study and research the bioactive ingredients from plants with antioxidant and antimicrobial activity as components for developing product formulations to meet the growing demand of consumers.

Pluchea indica (L.) Less (name as Khlu in Thailand) is a member of Asteraceae family and a well-known medicinal plants that grows naturally in many Asian countries. It could be found Thailand, India, China, Philippines, Malaysia and Myanmar [2, 3]. In Thailand, $P$. indica (L.) Less leaves are used as tea products because they are believed to play role an indigenous remedy due to their anti-diabetic properties [4]. It contains many biochemical compounds like sesquiterpenes, flavonoids, tannins, saponin, sterols, alkaloids and thiophenes [5]. It presented the various pharmacological activities such as antioxidant $[6,7]$, antimicrobial $[8,9]$, anti-inflammatory [10], anti-tumor [11], anti-cancer [12], antiproliferation [13], antidiabetic [14], anti-diuretic [15] activities. Thus, moisturizing lotion products, especially lotion bar was the skincare products that will be developed in this research. It is not only increase the moisturizing and strengthening for the skin to fight various pollutions, it is also a valuable addition to the antioxidant and antimicrobial activity from $P$. indica (L.) Less extracts that used as a bioactive ingredient in the development of natural lotion bar.

\section{MATERIALS AND METHODS}

\section{Plant material and preparation of extracts}

The leaves of $P$. indica (L.) Less (PI) in this study were obtained from the Thai Pharmacy Store, Mueang District, Saraburi Province. The plant material was dried in a hot air oven at $50^{\circ} \mathrm{C}$ for $3-5 \mathrm{~d}$ after cleaning with water (2-3 times). All dried leaves were extracted in $95 \%$ ethanol, $75 \%$ acetone and $99.8 \%$ dichloromethane in the ratio of 1:20 (plant: a solvent; $(\mathrm{w} / \mathrm{v})$ ) by maceration for $7 \mathrm{~d}$. Crude aqueous extract of PI leaf was prepared by boiling into distilled water (ratio of $1: 17.5$ ) at $60^{\circ} \mathrm{C}$ for $1 \mathrm{~h}$. Then, the filtrates were concentrated using a rotary vacuum evaporator under vacuum condition. The concentrated extracts of PI leaves were stored at-20 ${ }^{\circ} \mathrm{C}$ under dark condition until future use.

\section{Preliminary phytochemical screenings}

A small portion of the crude extracts was subjected to qualitative phytochemical analysis using standard procedure [16] with little modification.

\section{Estimation of total phenolic content (TPC)}

The quantitative of TPC was determined with Folin Ciocalteau (FC) reagent following prescribed methods [17] with a little modification. $750 \mu \mathrm{l}$ of $10 \%$ Folin-Ciocalteu reagent was thoroughly mixed with $100 \mu \mathrm{l}$ of plant extracted solution at a proper concentration $(0.2$ $\mathrm{mg} / \mathrm{ml}$ ) and then incubated at room temperature for $5 \mathrm{~min}$. After that, $750 \mu \mathrm{l}$ of $\mathrm{Na}_{2} \mathrm{CO}_{3}(6 \% \mathrm{w} / \mathrm{v})$ was added to the mixture solution. The resulting mixture was incubated and allowed to for $90 \mathrm{~min}$ under dark condition for the development of color. The absorbance of the samples was measured at $725 \mathrm{~nm}$ using spectrophotometer (Hanon instruments, Japan). The phenolic concentration was expressed as $\mathrm{mg}$ of gallic acid $(0.025-0.500 \mathrm{mg} / \mathrm{ml})$ equivalent per $100 \mathrm{~g}$ of dry weight. 


\section{Estimation of total flavonoid content (TFC)}

The amount of flavonoid in each crude extracts was analyzed by aluminum chloride colorimetric assay in accordance with the previous method [18]. A total of $200 \mu \mathrm{l}$ of sample extracts $(0.2$ $\mathrm{mg} / \mathrm{ml}$ ) was mixed with $2.3 \mathrm{ml}$ of methanol solution ( $30 \% \mathrm{w} / \mathrm{v}), 100$ $\mu \mathrm{l}$ of $0.5 \mathrm{M} \mathrm{NaNO}_{2}$ and $100 \mu \mathrm{l}$ of $0.3 \mathrm{M} \mathrm{AlCl}_{3}$, respectively. The resulting solution was thoroughly mixed and remained at room temperature for $5 \mathrm{~min}$ in the dark condition. The absorbance of mixture solution was measured spectrophotometrically at $506 \mathrm{~nm}$ against blank sample. The flavonoid concentration was expressed as $\mathrm{mg}$ of rutin $(0.25-5.00 \mathrm{mg} / \mathrm{ml})$ equivalent per $100 \mathrm{~g}$ of dry weight.

\section{In vitro antioxidant activities}

\section{DPPH radical scavenging activity}

The evaluation of scavenging ability of crude extract against free radical was conducted by 1,1-diphenyl-2-picrylhydrazyl (DPPH) assay [19] with a little modification. $100 \mu \mathrm{l}$ of sample extracts $(0.2$ $\mathrm{mg} / \mathrm{ml}$ ) was mixed to $900 \mu \mathrm{l}$ of $0.1 \mathrm{mmol} \mathrm{DPPH}$ in methanolic solution under vigorous shaking and allowed to stand for 20-30 min in dark at room temperature. The absorbance of solutions was then read at $517 \mathrm{~nm}$. The $\mathrm{IC}_{50}$ values (scavenge $50 \%$ of the radicals) of plant extract were calculated using linear regression graph as antioxidant activity. DPPH scavenging effect was calculated using the following formulation:

$$
\text { DPPH radical scavenging }(\%)=\left[\left(\mathrm{A}_{0}-\mathrm{A}_{1}\right) / \mathrm{A}_{0}\right] \times 100
$$

Where $A_{0}$ is the absorbance of the control and $A_{1}$ is the absorbance of sample extracts

\section{Ferric reducing/antioxidant power assay (FRAP)}

The ferric reducing antioxidant power (FRAP) of plant extracts was analyzed using tripyridyltriazine (TPTZ) solution with modified from the previous method [20]. FRAP reagent was prepared in acetate buffer (300 mmol, pH 3.6) and used freshly. After that, $2.7 \mathrm{ml}$ of the working FRAP reagent (warmed to $37^{\circ} \mathrm{C}$ before use) was thoroughly mixed to $300 \mu \mathrm{l}$ of sample extracts $(0.2 \mathrm{mg} / \mathrm{ml})$ and then incubated for $30 \mathrm{~min}$. the absorbance of the reaction mixtures was read at $596 \mathrm{~nm}$. Ascorbic acid (0.01-0.25 mg/ml) as standard solution was prepared the standard curve. The antioxidant capacity was expressed as mg of ascorbic acid equivalents $/ 100 \mathrm{~g}$ dry weight of the plant samples.

\section{Determination of antimicrobial activity}

\section{Microorganisms and culture condition}

Crude extracts were evaluated the antagonistic activities against 2 bacterial groups; 1) Gram-positive bacteria (Bacillus cereus DMST
5040, Enterococcus faecalis DMST 4736, Staphylococcus aureus ATCC 25923 and Staphylococcus epidermidis) and 2) Gram-negative bacteria (Escherichia coli ATCC 25922, Klebsiella pneumoniae, Pseudomonas aeruginosa ATCC 27853, Proteus mirabilis DMST 8212 and Salmonella typhimurium ATCC 13311). Bacterial strains were source from them Department of Biotechnology, King Mongkut's University of Technology North Bangkok, Thailand. All tested microorganisms were cultured and maintained on brain heart infusion (BHI, Difco) broth/agar medium under $37^{\circ} \mathrm{C}$ for $18-24 \mathrm{~h}$.

\section{Agar disc diffusion assay}

Antimicrobial activity was performed by agar disc diffusion assay at the concentration of 50,100,200,300 and $400 \mathrm{mg} / \mathrm{ml}$ against nine tested bacterial strains. In brief, the overnight cultures of tested bacterial strains were adjusted to $1.0 \times 10^{8-9} \mathrm{CFU} / \mathrm{ml}\left(\mathrm{OD}_{600}=0.2\right)$ in BHI broth by spectrophotometer. After that, the inoculums of pathogenic strains were spread on agar surface by sterile cotton swab and allowed to stand for 10-15 min. Then, sterile paper discs ( $6 \mathrm{~mm}$ in diameter) were placed on the surface of previous plates and followed by impregnation of extracts $(10-20 \mu \mathrm{l})$ at different concentrations. The diameter (mm) of the inhibition zones (IZ) was measured after 1,3 and $5 \mathrm{~d}$ incubation at $37^{\circ} \mathrm{C}$. [18]. The positive controls used were ampicillin (Amp, $10 \mu \mathrm{g} / \mathrm{ml}$ ) and ciprofloxacin (CIP, $10 \mu \mathrm{g} / \mathrm{ml}$ ) discs.

Minimum inhibitory concentration (MIC) and minimum bactericidal concentration (MBC) assay

The MIC values of the crude extracts was conducted by micro-dilution method [21]. The serial two-fold dilutions of the crude extracts were prepared at the concentrations ranging from 200 to $0.195 \mathrm{mg} / \mathrm{ml}$ with BHI broth in 96 -well plate. Then, $5 \mu \mathrm{l}$ of bacterial suspension $\left(10^{8-9}\right.$ $\mathrm{CFU} / \mathrm{ml}$; OD600 $=0.2$ ) was added to each wells. The micro-dilution trays were incubated at $37{ }^{\circ} \mathrm{C}$ for 2 h rs. Bacterial growth was detected by observing the first clear well which was considered as the MIC values. Then, all of the clear MIC well was transferred to the agar plates via loop to evaluate the MBC values. The growth controls (medium+inoculums) and sterility controls (medium+plant extracts) were performed simultaneously in this study.

\section{Development of lotion bar}

The based ingredients of lotion bar, including emulsifying agents, nourish agents, and oil phase ingredients were adjusted in order to produce an optimized lotion bar formulation (table 1). Each ingredient phases were prepared under heat condition $\left(70^{\circ} \mathrm{C}\right)$ and continuously stirred until a smooth uniform lotion (viscous solution). Then, the viscous solution was slowly poured into molds and allowed to stand until firm at room temperature.

Table 1: Ingredients of natural lotion bar formulations in this study

\begin{tabular}{|c|c|c|c|c|c|}
\hline \multirow[t]{3}{*}{ Ingredients } & \multicolumn{4}{|c|}{ Formulation (\%w/w) } & \multirow[t]{3}{*}{ Functions } \\
\hline & \multicolumn{2}{|c|}{ Basic formulas } & \multicolumn{2}{|c|}{ Developed formulas } & \\
\hline & 1 & 2 & 1 & 2 & \\
\hline \multicolumn{6}{|l|}{ Phase A } \\
\hline Coconut oil & 32.67 & 31.42 & 31.41 & 31.39 & Emulsifying/moisturizer \\
\hline Beeswax & 32.67 & 31.42 & 31.41 & 31.39 & Emulsifying \\
\hline Shea butter & & 31.42 & 31.41 & 31.39 & Emulsifying/moisturizer \\
\hline \multicolumn{6}{|l|}{ Phase B } \\
\hline $\begin{array}{l}\text { Vitamin B5 } \\
\text { (Pantothenic Acid) }\end{array}$ & - & 0.50 & 0.50 & 0.50 & Nourish agent (helping to soothe a dry and irritated skin) \\
\hline Plant extract & - & - & 0.004 & 0.041 & Skin conditioning/Active ingredient \\
\hline \multicolumn{6}{|l|}{ Phase C } \\
\hline Biocide & 2.00 & 0.25 & 0.25 & 0.25 & Preservative \\
\hline Fragrance & - & 5.00 & 5.00 & 5.00 & Fragrance \\
\hline Total & 100.00 & 100.00 & 100.00 & 100.00 & \\
\hline
\end{tabular}

\section{Evaluation of lotion bar}

\section{Physical evaluation}

Five grams of each formulated lotion bar were prepared for studying the physical appearance by organoleptic properties in terms of clarity, color, and odor. The $\mathrm{pH}$ of $1 \%$ solution of lotion bar was measured using the digital $\mathrm{pH}$ meter.

\section{Stability of the formulation}

All the formulated lotion bars were evaluated the stability at various storage conditions (placing at $5 \pm 2,25 \pm 2$, and $40 \pm 2{ }^{\circ} \mathrm{C}$ (six cycle; $75 \pm 5 \%$ relative humidity) for $6 \mathrm{w}$. The each formulation was examined for changes in appearance, color, odor, homogeneity and $\mathrm{pH}$. 


\section{Homogeneity test}

Each formulated lotion bar was tested the homogeneity by visual appearance and touch.

\section{Type of smear}

Formulated lotion bars were checked the type of smear formed on the skin after lotion bar application.

\section{Removal test}

Formulated lotion bars were tested the ease of removal by rinsing the part of applied lotion bar with tap water and minimal force to remove.

\section{After feel test}

The emollient and slipperiness of lotion bar formulation after the applying of lotion bar $(0.1 \mathrm{~g})$ was checked.

\section{Customer satisfaction survey}

Panelists $(n=30)$ used a 5-point hedonic scale (rate quality from dislike extremely to like extremely) to assess the consumer satisfaction.

\section{Microbial examination of lotion bar}

One gram of materials was aseptically transferred into the Erlenmeyer flask containing $50 \mathrm{ml}$ of sterile phosphate buffer ( $\mathrm{pH}$ 7.2). The tested solution was evaluated the microbial growth on BHI (for bacteria strains), PDA (for fungal strains) by pour plate technique. The microbial limits test were performed to detect the $P$. aeruginosa (Cetrimide agar), E. coli (MacConky agar), S. aureus (Mannital salt Agar) and Salmonella sp. (Xylage lysine deoxychalate Agar) on selective mediums in formulated lotion bars. Average number of colonies ( $\mathrm{CFU} / \mathrm{ml}$ ) was determined after incubating at $37^{\circ} \mathrm{C}$ for $24-72 \mathrm{~h}$ and $25^{\circ} \mathrm{C}$ for $3-7 \mathrm{~d}$ for bacteria and fungi, respectively.

\section{Statistical analysis}

Results were presented as mean $\pm S D(n=3)$. Statistical analyses were performed by one-way ANOVA and pair t-tests at 0.05 of significant level $(\mathrm{p} \leq 0.05)$.

\section{RESULTS AND DISCUSSION}

\section{Extracts yields (\%) and qualitative phytochemical analysis}

The yields of crude leaves extracts from Pluchea indica (L.) Less (PI) in this study obtained by maceration in different solvents including distilled water, $95 \%$ ethanol, $75 \%$ acetone and $99.8 \%$ chloroform. The highest yield of was observed for the aqueous $(18.37 \pm 0.56 \%$; $\mathrm{w} / \mathrm{v})$ crude extract followed by $95 \%$ ethanolic $(12.30 \pm 0.58 ; \mathrm{w} / \mathrm{v})$, $75 \%$ acetonic $(9.39 \pm 0.52 ; \mathrm{w} / \mathrm{v})$ crude extracts, respectively. The results of preliminary phytochemical analysis in crude extracts of PI leaves were given in table 2. Steroids, terpenoids and alkaloids as secondary metabolites were present in all the solvent extracts of PI leaves while anthraquinone and cardiac glycosides were absent from all the extracts (table 2).

Table 2: Preliminary phytochemical analysis of $P$. indica (L.) less leaves

\begin{tabular}{|c|c|c|c|c|}
\hline Phytochemical compounds & Distilled water & 95\% Ethanol & 75\% Acetone & 99.8\% Chloroform \\
\hline \multicolumn{5}{|l|}{ Saponins } \\
\hline Froth Test & +++ & - & - & - \\
\hline \multicolumn{5}{|l|}{ Tannins } \\
\hline $10 \% \mathrm{FeCl}_{3}$ & +++ & + & - & + \\
\hline \multicolumn{5}{|l|}{ Flavonoids } \\
\hline Shinoda Test & + & + & + & - \\
\hline $10 \%$ Lead (IV) acetate & +++ & +++ & ++ & - \\
\hline Anthraquinones & - & - & - & - \\
\hline \multicolumn{5}{|l|}{ Steroids } \\
\hline Libermann Test & + & + & + & + \\
\hline Keller-Kiliani Test & +++ & + & + & + \\
\hline \multicolumn{5}{|l|}{ Terpenoids } \\
\hline Salkowski Test & + & ++ & +++ & ++ \\
\hline \multicolumn{5}{|l|}{ Cardiac Glycosides } \\
\hline Kedde reagent & - & - & - & - \\
\hline Keller-Kiliani Test $+10 \% \mathrm{FeCl}_{3}$ Test & - & - & - & - \\
\hline \multicolumn{5}{|l|}{ Alkaloids } \\
\hline Dragendroff's reagent & + & ++ & + & + \\
\hline $28 \% \mathrm{NH}_{4} \mathrm{OH}$ & - & - & - & - \\
\hline Wangner's reagent & + & ++ & ++ & + \\
\hline
\end{tabular}

-= absent present; += trace (1-30\%);++= moderately present $(31-50 \%) ;+++=$ highly present $(>50 \%)$

In addition, it has noted that saponins were not detected in the aqueous, $75 \%$ acetonic and $99.8 \%$ chloroform extracts of PI leaves whereas flavonoids were found in all solvent extract except only 99.8\% chloroform extract. PI leaves extracts in aqueous and 95\% ethanolic contained the wide variety of secondary metabolites but in acetone and chloroform solvents showed the less variety of phytochemical compounds. Research proceeded by Kao et al. (2015) showed the similar results to this study, that is PI contains phenolics, flavonoids alkaloids and tannins [13]. Moreover, previous study found cardiac glycosides in PI leaves extracts [14], but not found in this study. These screened phytochemical compounds in this study are well known to support bioactive activities in medicinal plants which will be assessed next in this study.

Quantitative analysis of the total phenolic and flavonoid contents

The total phenolic content (TPC) of the PI extracts in various solvents were analyzed using the Folin-Ciocalteu reagent. The results indicated that TPC of $95 \%$ ethanolic extract of PI leaves (547.40 $\pm 1.60 \mathrm{mgGAE} / 100 \mathrm{~g}$ DW) was displayed higher than that of other solvent extracts followed by aqueous $(517.3 \pm 1.40$ mgGAE/100g DW), 75\% acetone (390.10 11.60 mgGAE/100g DW) and $99.8 \%$ chloroform extracts $(77.00 \pm 0.40 \mathrm{mgGAE} / 100 \mathrm{~g} \mathrm{DW})$ respectively (table 3 ). TPC of PI crude extracts $(177.00 \pm 0.40$ $547.40 \pm 1.60$ mgGAE/100g DW) obtained in this study was also different from other previous reports. It was lower than those of reported in 95\% ethanolic extract $(164.8 \mu \mathrm{g} \mathrm{GAE} / \mathrm{mg})$ [22] and methanolic extract $(37.99 \pm 1.39 \mu \mathrm{gGAE} / \mathrm{mg})[23]$ of PI, but it was higher than in methanol $(0.421 \pm 0.0026 \mathrm{mg} / \mathrm{ml})$ and water $(0.382 \pm 0.0269 \mathrm{mgGAE} / \mathrm{ml})$ extract of PI from Poland [24]. The total flavonoids content (TFC) was high in 95\% ethanolic extract (381.20 $\pm 0.10 \mathrm{mg}$ RE/100 $\mathrm{g}$ DW) followed by aqueous and $75 \%$ acetone extracts of PI leaves $(293.20 \pm 1.42$ and $245.40 \pm 0.26 \mathrm{mg}$ $\mathrm{RE} / 100 \mathrm{~g} \mathrm{DW}$, respectively) using aluminum chloride assay which was higher than TFC from Nonthaburi province, Thailand $(7.67 \pm 0.19$ mg CE/100g DW) from the previous study [25]. 
Table 3: Total phenolics and flavonoids contents and antioxidant activities of $P$. indica (L.) less leaves extracts

\begin{tabular}{|c|c|c|c|c|}
\hline \multirow[t]{2}{*}{ Tests } & \multicolumn{4}{|c|}{ Solvent extraction } \\
\hline & Distilled water & 95\% Ethanol & 75\% Acetone & 99.8\% Chloroform \\
\hline Total Phenolic Content (mg GAE/100g DW) & $517.3 \pm 1.40$ & $547.40 \pm 1.60^{*}$ & $390.10 \pm 1.60$ & $177.00 \pm 0.40$ \\
\hline Total flavonoids Content (mg RE/100g DW) & $293.20 \pm 1.42$ & $381.20 \pm 0.10^{*}$ & $245.40 \pm 0.26$ & $107.60 \pm 0.12$ \\
\hline \multicolumn{5}{|l|}{ Antioxidant Capacity } \\
\hline FRAP assay (mg AAE/100 g DW) & $15.40 \pm 0.50$ & $98.00 \pm 1.72 *$ & $87.20 \pm 1.91$ & $62.00 \pm 0.12$ \\
\hline DPPH assay (mg AAE/100g DW) & $58.20 \pm 0.20$ & $128.40 \pm 0.40^{*}$ & $81.20 \pm 0.40$ & $75.71 \pm 0.38$ \\
\hline \% Inhibition (DPPH) & $57.71 \pm 0.38$ & $61.37 \pm 0.41^{*}$ & $48.61 \pm 0.32$ & $43.99 \pm 0.29$ \\
\hline $\mathrm{IC}_{50}$ Sample; $\mu \mathrm{g} / \mathrm{ml}$ & $11.00 \pm 0.40$ & $6.80 \pm 0.04^{*}$ & $73.40 \pm 0.20$ & $17.40 \pm 0.30$ \\
\hline
\end{tabular}

$\mathrm{GAE}=$ Gallic Acid Equivalent; RE = Rutin Equivalent; $\mathrm{AAE}=$ Ascorbic acid Equivalent; $\mathrm{IC}_{50}=50 \%$ Inhibitory Concentration; ${ }^{*}=\mathrm{P} \leq 0.05$

The results of quantitative antioxidant activities revealed the TPC and TFC were consistent in the same direction, but their result was different in various solvents due to the varied solvent polarities. This suggested that the phenolic compounds of this plant might primarily contain flavonoids. The polarity of the solvent is very important in enhancing the solubility of phenolic compounds [26]. Furthermore, differences in the number and concentration of plant secondary metabolites were depending on these factors; the species of plant, parts of plant, stage of development, seasons and external factors such as light conditions, temperature and water stress [27, 28].

\section{Antioxidant activity}

The ferric reducing antioxidant power (FRAP) and DPPH radical scavenging activity results were given in table 3 . The solvent extracts of PI leaves with the highest antioxidant activity was 95\% ethanol with $98.00 \pm 1.72 \mathrm{mgAAE} / 100 \mathrm{~g} \mathrm{DW}$ and the lowest antioxidant activity was distilled water with $15.40 \pm 0.50$ mgAAE/100 g DW by FRAP assay. Regarding of DPPH radical scavenging assay, higher DPPH radical scavenging activity has a lower $\mathrm{IC}_{50}$ values. About $95 \%$ ethanolic extract of PI leaves significantly revealed the highest DPPH activity with the $\mathrm{IC}_{50}$ value of $6.80 \pm 0.04 \mu \mathrm{g} / \mathrm{ml}$ (\%inhibition of $61.37 \pm 0.41$ ). This value was rather close to the previous study which had $\mathrm{IC}_{50}$ of $4.34 \pm 0.42 \mu \mathrm{g} / \mathrm{ml}$ [23], while $\mathrm{IC}_{50}$ of standard ascorbic acid in this study was $0.166 \pm 0.010 \mu \mathrm{g} / \mathrm{ml}$. Previous studies have shown that phenolic compounds contribute to the antioxidant activity of plants. There was the significantly positive correlation between antioxidant activity (DPPH assay) and TPC with 95\% ethanolic extract ( $\mathrm{p} \leq 0.05$ ) in this study. Because phenolic compounds are good electron donors (hydrogen atoms to free radicals) [29]. Aqueous extract displayed a significantly negative correlation between total flavonoids content and antioxidant capacities by FRAP assay in this study ( $\mathrm{p} \leq 0.05)$.

\section{Antimicrobial activity}

All crude leaves extracts of PI were screened for antagonistic activity by agar disc diffusion method against nine pathogenic strains. The different degrees of the antimicrobial activities of the PI extracts were showed in table 4 . The most potent antimicrobial activities against S. aureus ATCC 25923 is attributed to $95 \%$ ethanolic extract which exhibited a very strong inhibitory activity at $200 \mathrm{mg} / \mathrm{ml}$ with inhibition zones of $46.67 \pm 0.58 \mathrm{~mm}(\mathrm{p} \leq 0.05)$ while showed weak inhibitory effect on $S$. epidermidis, $E$. coli ATCC 25922, $K$. pneumoniae, P. aeruginosa ATCC 27853, P. mirabilis DMST 8212 and S. typhimurium ATCC 13311 at $100 \mathrm{mg} / \mathrm{ml}$ with IZs of $7.00 \pm 0.00$ $8.00 \pm 0.00 \mathrm{~mm}$. S. aureus ATCC 25923 was the most sensitive strain to all extract of PI leaves, whereas B. cereus DMST 5040 and $P$. mirabilis DMST 8212 was significantly resistant to all solvent extracts of PI leaves except $95 \%$ ethanolic extract for P. mirabilis DMST $8212(\mathrm{p} \leq 0.05)$. Similar bacteriostatic activity in aqueous extract of PI leaves, especially against $E$. coli (concentrations of 25 to $100 \mathrm{mg} / \mathrm{ml} ; \quad$ IZs of $14.6-21.0 \mathrm{~mm})$ and $K$. pneumoniae (concentrations of 50 to $100 \mathrm{mg} / \mathrm{ml}$; IZs of $11.7-18.6 \mathrm{~mm}$ ) was recorded in previous study [30]. Ampicillin (15.67 $\pm 0.58-41.33 \pm 0.58$ $\mathrm{mm})$ and ciprofloxacin $(21.67 \pm 0.58-41.67 \pm 0.58 \mathrm{~mm})$ used as a positive control was effective against all the bacteria except $E$. coli ATCC 25922 and S. typhimurium ATCC 13311 for ampicillin and $S$. typhimurium ATCC 13311 for ciprofloxacin.

Table 4: Antibacterial activities of $P$. indica (L.) Less leaves extracts against some bacterial pathogens

\begin{tabular}{|c|c|c|c|c|c|c|c|c|c|c|}
\hline \multirow{3}{*}{$\begin{array}{l}\text { Concentration } \\
(\mathrm{mg} / \mathrm{ml})\end{array}$} & & \multicolumn{9}{|c|}{ Inhibition zone (IZ; $\varnothing=6 \mathrm{~mm}) ; \mathrm{mm} \pm S D$} \\
\hline & & \multicolumn{4}{|c|}{ Gram positive strains } & \multicolumn{5}{|c|}{ Gram negative strains } \\
\hline & & BC & EF & SA & SE & EC & $\mathbf{K P}$ & PA & PM & ST \\
\hline Distilled & 50 & $\mathrm{R}$ & $\mathrm{R}$ & $20.33 \pm 0.58^{1}$ & $6.50 \pm 0.00^{\mathrm{s}}$ & $7.83 \pm 0.29 \mathrm{qr}$ & $7.00 \pm 0.00^{\mathrm{r}}$ & $6.50 \pm 0.00^{\mathrm{s}}$ & $\mathrm{R}$ & $10.33 \pm 0.58^{\mathrm{n}}$ \\
\hline \multirow[t]{4}{*}{ Water } & 100 & $\mathrm{R}$ & $\mathrm{R}$ & $28.00 \pm 0.00^{\mathrm{i}}$ & $6.50 \pm 0.00^{\mathrm{s}}$ & $8.00 \pm 0.00 \mathrm{pq}$ & $7.00 \pm 0.00^{\mathrm{r}}$ & $6.50 \pm 0.00^{\mathrm{s}}$ & $\mathrm{R}$ & $9.67 \pm 0.58^{n}$ \\
\hline & 200 & $\mathrm{R}$ & $\mathrm{R}$ & $40.50 \pm 0.50^{c}$ & $6.50 \pm 0.00$ s & $8.00 \pm 0.00 \mathrm{pq}$ & $7.00 \pm 0.00 \mathrm{r}$ & $6.50 \pm 0.00^{s}$ & $\mathrm{R}$ & $8.17 \pm 0.29^{\circ} \mathrm{p}$ \\
\hline & 300 & $\mathrm{R}$ & $\mathrm{R}$ & $34.33 \pm 0.58^{f}$ & $6.50 \pm 0.00^{s}$ & $7.67 \pm 0.29 \mathrm{qr}$ & $7.00 \pm 0.00^{r}$ & $6.50 \pm 0.00^{s}$ & $\mathrm{R}$ & $8.00 \pm 0.00 \mathrm{pq}$ \\
\hline & 400 & $\mathrm{R}$ & $\mathrm{R}$ & $34.67 \pm 0.58^{f}$ & $6.50 \pm 0.00^{s}$ & $7.83 \pm 0.19 q \mathrm{qr}$ & $7.00 \pm 0.00^{\mathrm{r}}$ & $6.50 \pm 0.00^{\mathrm{s}}$ & $\mathrm{R}$ & $8.00 \pm 0.00$ \\
\hline $95 \%$ & 50 & $\mathrm{R}$ & $\mathrm{R}$ & $31.67 \pm 1.15^{\mathrm{gh}}$ & $7.00 \pm 0.00^{r}$ & $8.00 \pm 0.00 \mathrm{pq}$ & $7.00 \pm 0.00^{\mathrm{r}}$ & $7.00 \pm 0.00^{\mathrm{r}}$ & $7.00 \pm 0.00^{\mathrm{r}}$ & $7.00 \pm 0.00^{\mathrm{r}}$ \\
\hline \multirow{4}{*}{ Ethanol } & 100 & $\mathrm{R}$ & $\mathrm{R}$ & $37.00 \pm 0.00^{\mathrm{e}}$ & $7.00 \pm 0.00^{r}$ & $8.00 \pm 0.00 \mathrm{pq}$ & $7.00 \pm 0.00^{\mathrm{r}}$ & $7.00 \pm 0.00^{\mathrm{r}}$ & $7.00 \pm 0.00^{\mathrm{r}}$ & $7.00 \pm 0.00^{\mathrm{r}}$ \\
\hline & 200 & $\mathrm{R}$ & $\mathrm{R}$ & $46.67 \pm 0.58^{a}$ & $7.00 \pm 0.00^{r}$ & $8.00 \pm 0.00 \mathrm{pq}$ & $7.00 \pm 0.00 \mathrm{r}$ & $7.00 \pm 0.00 \mathrm{r}$ & $7.00 \pm 0.00 \mathrm{r}$ & $7.00 \pm 0.00^{r}$ \\
\hline & 300 & $\mathrm{R}$ & $\mathrm{R}$ & $44.00 \pm 1.00^{b}$ & $7.00 \pm 0.00^{r}$ & $8.00 \pm 0.00 \mathrm{pq}$ & $7.00 \pm 0.00^{\mathrm{r}}$ & $7.00 \pm 0.00^{\mathrm{r}}$ & $7.00 \pm 0.00^{\mathrm{r}}$ & $7.00 \pm 0.00^{\mathrm{r}}$ \\
\hline & 400 & $\mathrm{R}$ & $7.00 \pm 0.00 \mathrm{r}$ & $46.33 \pm 1.15^{a}$ & $8.00 \pm 0.00 \mathrm{pq}$ & $8.00 \pm 0.00 \mathrm{pq}$ & $7.00 \pm 0.00 \mathrm{r}$ & $7.00 \pm 0.00^{r}$ & $7.00 \pm 0.00 \mathrm{r}$ & $7.00 \pm 0.00 \mathrm{r}$ \\
\hline $75 \%$ & 50 & $\mathrm{R}$ & $7.00 \pm 0.00^{r}$ & $21.67 \pm 0.58^{\mathrm{k}}$ & $\mathrm{R}$ & $\mathrm{R}$ & $7.00 \pm 0.00^{\mathrm{r}}$ & $6.50 \pm 0.00^{\mathrm{s}}$ & $\mathrm{R}$ & $\mathrm{R}$ \\
\hline \multirow[t]{4}{*}{ Acetone } & 100 & $\mathrm{R}$ & $7.00 \pm 0.00^{r}$ & $38.00 \pm 0.00^{d}$ & $\mathrm{R}$ & $\mathrm{R}$ & $7.00 \pm 0.00^{\mathrm{r}}$ & $6.50 \pm 0.00^{\mathrm{s}}$ & $\mathrm{R}$ & $\mathrm{R}$ \\
\hline & 200 & $\mathrm{R}$ & $7.00 \pm 0.00^{r}$ & $30.67 \pm 1.15^{h}$ & $\mathrm{R}$ & $\mathrm{R}$ & $7.00 \pm 0.00^{\mathrm{r}}$ & $6.50 \pm 0.00^{\mathrm{s}}$ & $\mathrm{R}$ & $\mathrm{R}$ \\
\hline & 300 & $\mathrm{R}$ & $7.00 \pm 0.00^{r}$ & $30.00 \pm 0.00^{h}$ & $\mathrm{R}$ & $\mathrm{R}$ & $7.00 \pm 0.00^{\mathrm{r}}$ & $6.50 \pm 0.00^{\mathrm{s}}$ & $\mathrm{R}$ & $\mathrm{R}$ \\
\hline & 400 & $\mathrm{R}$ & $7.00 \pm 0.00^{r}$ & $39.33 \pm 1.53^{c}$ & $7.00 \pm 0.00$ & $\mathrm{R}$ & $7.00 \pm 0.00^{\mathrm{r}}$ & $6.50 \pm 0.00^{\mathrm{s}}$ & $\mathrm{R}$ & $\mathrm{R}$ \\
\hline $99.8 \%$ & 50 & $\mathrm{R}$ & $\mathrm{R}$ & $19.33 \pm 1.15^{1}$ & $7.00 \pm 0.00^{r}$ & $\mathrm{R}$ & $\mathrm{R}$ & $7.00 \pm 0.00^{r}$ & $\mathrm{R}$ & $7.00 \pm 0.00^{r}$ \\
\hline \multirow[t]{4}{*}{ Chloroform } & 100 & $\mathrm{R}$ & $\mathrm{R}$ & $16.67 \pm 0.58^{\mathrm{m}}$ & $7.00 \pm 0.00^{r}$ & $\mathrm{R}$ & $\mathrm{R}$ & $7.00 \pm 0.00^{r}$ & $\mathrm{R}$ & $7.00 \pm 0.00^{r}$ \\
\hline & 200 & $\mathrm{R}$ & $\mathrm{R}$ & $28.33 \pm 0.58^{i}$ & $7.00 \pm 0.00^{r}$ & $\mathrm{R}$ & $\mathrm{R}$ & $7.00 \pm 0.00^{r}$ & $\mathrm{R}$ & $7.00 \pm 0.00^{r}$ \\
\hline & 300 & $\mathrm{R}$ & $\mathrm{R}$ & $24.33 \pm 1.15^{j}$ & $7.00 \pm 0.00^{r}$ & $\mathrm{R}$ & $\mathrm{R}$ & $7.00 \pm 0.00^{\mathrm{r}}$ & $\mathrm{R}$ & $7.00 \pm 0.00^{\mathrm{r}}$ \\
\hline & 400 & $\mathrm{R}$ & $\mathrm{R}$ & $31.67 \pm 0.58^{\mathrm{gh}}$ & $7.00 \pm 0.00^{\mathrm{r}}$ & $\mathrm{R}$ & $\mathrm{R}$ & $7.00 \pm 0.00^{\mathrm{r}}$ & $\mathrm{R}$ & $7.00 \pm 0.00^{\mathrm{r}}$ \\
\hline
\end{tabular}

Abcdefghijklmnopqrs $=$ significant at the 0.05 level $(\mathrm{p} \leq 0.05) . \mathrm{BC}=$ B. cereus DMST 5040, EF $=$ E. faecalis DMST 4736, SA $=$ S. aureus ATCC $25923, \mathrm{SE}=$ S. epidermidis, $\mathrm{EC}=$ E. coli $\mathrm{ATCC} 25922, \mathrm{KP}=$ K. pneumoniae, $\mathrm{PA}=$ P. aeruginosa $\mathrm{ATCC} 27853, \mathrm{PM}=P$. mirabilis $\mathrm{DMST} 8212$ and $\mathrm{ST}=S$. typhimurium ATCC 13311; R: Resistance 
Interestingly, crude aqueous and 95\% ethanolic extracts of PI leaves had a bactericidal effect on both Gram-positive and Gram negative stains with the $\mathrm{MBC}$ values of $50-200 \mathrm{mg} / \mathrm{ml}$ (table 5). At the concentration of $50 \mathrm{mg} / \mathrm{ml}$ of plant extract, S. aureus ATCC 25923 and B. cereus DMST 5040 (Gram-positive bacterias) were destroyed by $95 \%$ ethanolic extracts while was only S. aureus ATCC 25923 in aqueous extracts. Among gram negative bacterial strains, the bactericidal concentration of $95 \%$ ethanolic extract at 100 $\mathrm{mg} / \mathrm{ml}$ (MBC values) was found in K. pneumoniae, P. aeruginosa ATCC 27853; and S. typhimurium ATCC 13311 but found in $K$ pneumoniae with aqueous extract. The previous studies presented the similar result of potential antibacterial activities of ethanol PI extract against B. cereus (MIC and MBC of $500 \mu \mathrm{g} / \mathrm{ml}$ ), S. aureus (MIC and $\mathrm{MBC}$ value of $500 \mu \mathrm{g} / \mathrm{ml}$ ) and $E$. coli (MIC value of $2,000 \mu \mathrm{g} / \mathrm{ml}$ ), but it is no potential against $P$. aeruginosa, which this study had anti$P$. aeruginosa by broth micro-dilution method [31].

Comparisons of antibacterial activities all solvent extracts on both assays, the result of MIC part of the crude aqueous and $95 \%$ ethanolic extracts was in conformity with their inhibition zone of antimicrobial activity in only the case of S. aureus ATCC 255923, which showed the strong inhibitory effect its growth. In this study, gram-negative bacterias had more tolerance to PI leaves extracts than gram-positive bacterias due to the presence of an outer membrane (lipopolysaccharide) in gram-negative bacteria. Moreover, plant active compounds (phenolics, flavonoids, tannins, steroids, terpenoids and alkaloids) is capable of damage protein of cell membrane (lipid bilayer) by damaging the proteins and penetrating into bacterial cells to inhibit and destroy bacterial cells [32].

Table 5: The MIC and MBC values of $P$. indica (L.) Less leaves extracts against some pathogenic strains by broth micro-dilution method

\begin{tabular}{|c|c|c|c|c|c|c|c|c|c|}
\hline \multirow[t]{3}{*}{ Solvents extraction } & \multicolumn{9}{|c|}{ Microorganisms } \\
\hline & \multicolumn{4}{|c|}{ Gram positive strains } & \multicolumn{5}{|c|}{ Gram negative strains } \\
\hline & BC & EF & SA & SE & EC & KP & PA & PM & ST \\
\hline \multicolumn{10}{|l|}{ Distilled water } \\
\hline MIC (mg/ml) & 100 & 50 & 25 & 100 & 200 & 50 & 100 & 200 & 100 \\
\hline $\mathrm{MBC}(\mathrm{mg} / \mathrm{ml})$ & 200 & 100 & 50 & 200 & $>200$ & 100 & 200 & $>200$ & 200 \\
\hline \multicolumn{10}{|l|}{ 95\% Ethanol } \\
\hline MIC (mg/ml) & 50 & 100 & 25 & 200 & 100 & 100 & 100 & 100 & 100 \\
\hline $\mathrm{MBC}(\mathrm{mg} / \mathrm{ml})$ & 50 & 200 & 50 & $>200$ & $>200$ & 100 & 100 & 200 & 100 \\
\hline \multicolumn{10}{|l|}{$75 \%$ Acetone } \\
\hline MIC (mg/ml) & $>200$ & $>200$ & 200 & $>200$ & $>200$ & $>200$ & 100 & 200 & $>200$ \\
\hline $\mathrm{MBC}(\mathrm{mg} / \mathrm{ml})$ & $>200$ & $>200$ & 200 & $>200$ & $>200$ & $>200$ & 200 & 200 & $>200$ \\
\hline \multicolumn{10}{|l|}{ 99.8\% Chloroform } \\
\hline MIC (mg/ml) & $>200$ & $>200$ & 200 & $>200$ & $>200$ & $>200$ & $>200$ & $>200$ & $>200$ \\
\hline $\mathrm{MBC}(\mathrm{mg} / \mathrm{ml})$ & $>200$ & $>200$ & 200 & $>200$ & $>200$ & $>200$ & $>200$ & $>200$ & $>200$ \\
\hline \multicolumn{10}{|l|}{ Antibiotics } \\
\hline \multicolumn{10}{|l|}{ Ampicillin } \\
\hline MIC $(\mu \mathrm{g} / \mathrm{ml})$ & 0.039 & 0.009 & 0.156 & 0.009 & 0.156 & 0.009 & 0.019 & 0.019 & 0.078 \\
\hline MBC $(\mu \mathrm{g} / \mathrm{ml})$ & 0.039 & 0.009 & 0.156 & 0.019 & 0.156 & 0.009 & 0.019 & 0.039 & 0.078 \\
\hline \multicolumn{10}{|l|}{ Ciprofloxacin } \\
\hline MIC $(\mu \mathrm{g} / \mathrm{ml})$ & 0.078 & 0.313 & 0.019 & 0.001 & 0.019 & 0.313 & 0.009 & 0.004 & 0.078 \\
\hline $\operatorname{MBC}(\mu \mathrm{g} / \mathrm{ml})$ & 0.156 & 0.625 & 0.039 & 0.002 & 0.019 & 0.625 & 0.019 & 0.039 & 0.156 \\
\hline
\end{tabular}

$\mathrm{BC}=$ B. cereus $\mathrm{DMST} 5040 ; \mathrm{EF}=$ E. faecalis DMST 4736; $\mathrm{SA}=$ S. aureus $\mathrm{ATCC} 25923 ; \mathrm{SE}=$ S. epidermidis, $\mathrm{EC}=$ E. coli $\mathrm{ATCC} 25922 ; \mathrm{KP}=$ K. pneumoniae; $\mathrm{PA}=$ P. aeruginosa ATCC 27853; $\mathrm{PM}=$ P. mirabilis DMST 8212 and ST $=$ S. typhimurium ATCC 13311; All results \pm 0.00 (SD.)

\section{Lotion bars formulation}

Crude 95\% ethanolic extracts of PI leaves was chosen to apply in formulation development of natural lotion bar as an active ingredient based on its higher antioxidant ( $\mathrm{IC}_{50}$ of $6.80 \pm 0.04 \mu \mathrm{g} / \mathrm{ml}$ ) and antimicrobial actions (broad spectrum). Developed formula 1 and formula 2 contain $95 \%$ ethanolic extract of PI leaves at concentration of $10(0.0041 \%)$ and $100(0.0410 \%)$ times of $\mathrm{IC}_{50}$ value, respectively (table 1 ).

\section{Evaluation of natural lotion bars}

This study was aimed to developed the lotion bar formulation containing $P$. indica (L.) less extract. Comparisons of the effects of each formulation on stability and acceptance are important factors that must be studied for the good quality of the upcoming products. The results of the evaluation of formulated lotions bar indicated that the color, odor and homogeneity of the lotion bar were stable during the freeze-Thaw ( $6^{\text {th }}$ cycles) of observation (table 6 ). The $\mathrm{pH}$ values of the both developed formula 1 and 2 remained constant with a slight decrease in the value. The color of developed lotion bar (1) and (2) was yellowish-white and slightly yellowish, respectively (fig. 1). The $\mathrm{pH}$ values of the lotion bar was presented in range of 5.1 to 5.7. Developed formula 1 of lotion bar shows the $\mathrm{pH}$ value in the range that is better than developed formula 2 of that for human skin $\mathrm{pH}$ (average $\mathrm{pH}=5.5$ ).

Table 6: Stability of lotion bar containing $P$. indica $(L$.$) less leaves extract$

\begin{tabular}{llll}
\hline Storage condition/Test & Developed formula 1 & & Developed formula 2 \\
\cline { 2 - 3 } & Initial & Final & Initial \\
\hline $25 \pm 2{ }^{\circ} \mathrm{C} / 75 \% \mathrm{RH}$ & & & Final \\
Color & yellowish-white & unchanged & slightly yellowish \\
Odor & Pleasant & unchanged & Pleasant \\
Homogeneity & Satisfactory & unchanged & Satisfactory \\
pH & $5.6 \pm 0.02$ & $5.7 \pm 0.02$ & $5.1 \pm 0.02$ \\
Freeze-Thaw $\left(6^{\text {th }}\right.$ cycles) & & & unchanged \\
Color & yellowish-white & unchanged & slightly yellowish \\
Odor & Pleasant & unchanged & Pleasant \\
Homogeneity & Satisfactory & unchanged & Satisfactory \\
pH & $5.6 \pm 0.02$ & $5.7 \pm 0.02$ & unchanged \\
\hline
\end{tabular}


Both developed lotion bar formulations had a homogeneous distribution of extracts with the other components that was asserted by the appearance and touch when both formulations were kept for long time. After the application of both developed lotion bar $(0.1 \mathrm{~g})$ on skin, emollient and slipperiness of lotion bar was found and easily removed by washing with tap water. Satisfaction test of developed lotion bar formula 1 and 2 was evaluated in terms of appearance, odor, color, after feel, packaging and overall acceptability by 5-point hedonic scales ( $\mathrm{n}=30$ persons). The acceptability scores of lotion bar formulate 1 showed higher score in all terms compared with f lotion bars formulate 2 . The overall acceptability scores from customer satisfaction of lotion bar formula 1 and 2 were $4.23 \pm 0.57$ (like moderately) and $3.80 \pm 0.66$ (like moderately), respectively while commercial lotion bar was as $4.47 \pm 0.57$ (like moderately).

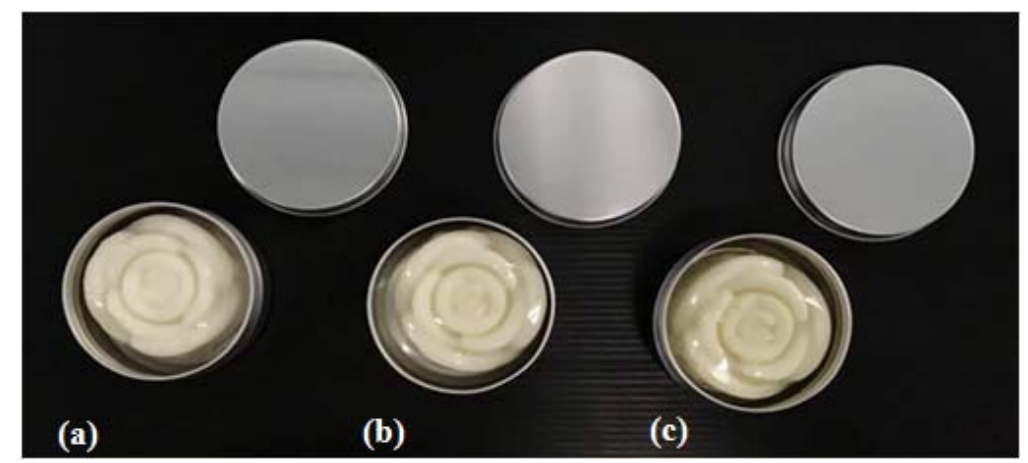

Fig. 1: Physical appearance of formulated natural lotion bars; based formula (a), Developed formula 1 (b; $0.0041 \%$ of extract) and Developed formula 2 (c; $\mathbf{0 . 0 4 1 0 \%}$ of extract)

\section{CONCLUSION}

The crude extract of Pluchea indica (L.) Less leaves contains the many phytochemical constituents including saponins, tannins, flavonoids steroids, terpenoids and alkaloids. The types of secondary metabolites from plant materials depended on the polarity of the solvent used for extraction. 95\% ethanolic extract of PI leaves noticeably displayed stronger antioxidant and antimicrobial activities than other solvents (distilled water, $75 \%$ acetone and $99.8 \%$ chloroform). It showed broad spectrum of inhibiting (nine bacterial strains) and killing (seven bacterial strains) for both Gram-negative and Gram-positive bacteria especially $S$. aureus ATCC 25923 with IZ of $16.67 \pm 0.58-46.67 \pm 0.58 \mathrm{~mm}$ (MICs and MBCs of 25 and $50 \mathrm{mg} / \mathrm{ml}$, respectively). Furthermore, 95\% ethanolic extract showed the highest total of phenolic and flavonoid contents and antioxidant activities (DPPH and FRAP assay) as $61.37 \pm 0.41 \%$ of inhibition and $\mathrm{IC}_{50}$ value of $6.80 \pm 0.04 \mu \mathrm{g} / \mathrm{ml}$ by DPPH assay. Accordingly, the PI leaves extract in $95 \%$ ethanol was as a rich source of antioxidant and antibacterial compounds that had reasonable component as a bioactive ingredient to apply for development of lotion bars formulation. Based on organoleptic properties, stability and consumer satisfaction test, PI (moisturizing) lotion bar formula 1 is a suitable formula for further study in the field of allergic and cytotoxicity testing for further commercial development.

\section{ACKNOWLEDGEMENT}

I would like to thank the Faculty of Applied Sciences, King Mongkut's University of Technology North Bangkok (No. 643055) for financial support.

\section{AUTHORS CONTRIBUTIONS}

All the authors have contributed equally.

\section{CONFLICTS OF INTERESTS}

The authors report no conflicts of interest.

\section{REFERENCES}

1. Shah R, Jindal A, Patel NM. Acrochordons as a cutaneous sign of metabolic syndrome: a case-control study. Ann Med Health Sci Res 2014;4:202-5.

2. Wang J, Pei YH, Lin WH, Deng ZW, Qiao L. Chemical constituents from the stems and leaves of marine mangrove plant Pluchea indica (L.) less. Shenyang Yaoke Daxue Xuebao 2008;25:960-3.

3. Panda SK, Luyten W. Antiparasitic activity in asteraceae with special attention to ethnobotanical use by the tribes of Odisha, India. Parasite 2018;25:10-25.
4. Kongkiatpaiboon S, Chewchinda S, Vongsak B. Optimization of extraction method and HPLC analysis of six caffeoylquinic acids in Pluchea indica leaves from different provenances in Thailand. Revista Brasileira Farmacognosia 2018;28:145-50.

5. Ruan J, Li Z, Yan J, Huang P, Yu H, Han L, et al. Bioactive constituents from the aerial parts of Pluchea indica less. Molecules 2018;23:2104.

6. Noridayu AR, Hii YF, Faridah A, Khozirah S, Lajis N. Antioxidant and antiacetylcholinesterase activities of Pluchea indica less. Int Food Res J 2011;18:925-9.

7. Widyawati PS, Wijaya $\mathrm{CH}$, Hardjosworo PS, Sajuthi D. Antioxidant activity of pluchea (Pluchea indica Less) leaves methanolic extract and its fractions. Agritech 2012;32:249-57.

8. Biswas R. Isolation, purification and characterization of four pure compounds from the root extract of Pluchea indica less and the potentiality of the root extract and the pure compounds for antimicrobial activity. Eur Bull Drug Res 2005;3:63-70.

9. Qiu YQ, Qi SH, Zhang S, Tian XP, Xiao ZH, Li MY, et al. Thiophene derivatives from the aerial part of Pluchea indica. Heterocycles 2008;75:1757-64.

10. Srisook K, Buapool D, Boonbai R, Panadda S, Charoensuk Y, Srisook E. Antioxidant and anti-inflammatory activities of hot water extract from Pluchea indica less. herbal tea. J Med Plants Res 2012;6:4077.

11. Goswami S, Debnath $\mathrm{S}$, Karan $\mathrm{S}$, Chatterjee TK. In vivo antitumor activity of phytochemical pitc-2 obtained from tissue cultured plant Pluchea indica on sarcoma-180 solid tumor mice model. Asian J Pharm Clin Res 2018;11:211-8.

12. Cho JJ, Cho CL, Kao CL, Chen CM, Tseng CN, Lee YZ, et al. Crude aqueous extracts of Pluchea indica (L.) less. inhibit proliferation and migration of cancer cells through induction of p53dependent cell death. BMC Complem Altern Med 2012;12:265.

13. Kao CL, Cho J, Lee YZ, Cheng YB, Chien CY, Hwang CF, et al. Ethanolic extracts of Pluchea indica induce apoptosis and antiproliferation effects in human nasopharyngeal carcinoma cells. Molecules 2015;20:11508-23.

14. Widyawati PS, Budianta TDW, Gunawan DI, Wongso RS Evaluation antidiabetic activity of various leaf extracts of Pluchea indica less. Int J Pharm Pharm Res 2015;7:597-603.

15. Pramanik KC, Bhattacharya P, Biswas R, Bandyopadhyay D, Mishra M, Chatterjee T. Hypoglycemic and antihyperglycemic activity of leaf extract of Pluchea indica less. Orient Pharm Exp Med 2006;6:232-6

16. Harborne JB. Phytochemical methods, a guide to modern techniques of plant analysis. London: Chapman and Hall; 1998. p. $182-90$ 
17. Singleton VL, Orthofer R, Lamuela Raventos RM. Analysis of total phenols and other oxidation substrates and antioxidants by means of folin-ciocalteu reagent. Methods Enzymol 1999;299:152-78.

18. Tinrat S, Singhapol C. Evaluation of antioxidant and antibacterial activities of Vernonia amygdalina leaf extracts as an auxiliary in natural hair shampoo. J Pharm Clin Res 2020;13:50-7.

19. Jayalakshmia B, Raveeshab KA, Muralic M, Amruthesh KN. Phytochemical, antibacterial and antioxidant studies on leaf extracts of Piper betle L. Int J Pharm Pharm Sci 2015;7:23-9.

20. Benzie IF, Strain JJ. The ferric reducing ability of plasma (FRAP) as a measure of antioxidant power: the FRAP assay. Anal Biochem 1996;239:70-6.

21. CLSI (Clinical and Laboratory Standards Institute). Methods for dilution antimicrobial susceptibility tests for bacteria that grow aerobically; approved standard. $7^{\text {th }}$ ed. Document M7-A7, Wayne, PA; 2006.

22. Indradi RB, Fidrianny I, Wirasutisna KR. DPPH scavenging activities and phytochemical content of four asteraceae plants. Int J Pharmacogn Phytochem Res 2017;9:755-9.

23. Syabana MA, Yuliana ND, Batubara R, Fardiaz D. Antidiabetic activity screening and nmr profile of vegetable and spices commonly consumed in Indonesia. Food Sci Tech 2020;1-11. https://doi.org/10.1590/fst.14120

24. Yuliani, Soemarno, Yanuwiadi B, Leksono AS. Total phenolic and flavonoid contents of Pluchea indica Less leaves extracts from some altitude habitats. Int J ChemTech Res 2015;8:1618-25.
25. Vongsak B, Inson N, Jaisamut S. Effect of Pluchea indica extracts from different habitats and seasons on free radical scavenging capacity. Thai J Pharm Sci 2017;41 Suppl 1:169-72.

26. Cheung LM, Cheung PCK, Ooi VEC. Antioxidant activity and total phenolics of edible mushroom extracts. Food Chem 2003;81:249-55.

27. Isah T. Stress and defense responses in plant secondary metabolites production. Biol Res 2019;52:39.

28. Zlatic N, Jakovljevic D, Stankovic M. Temporal, plant part, and interpopulation variability of secondary metabolites and antioxidant activity of Inula helenium L. Plants (Basel) 2019;8:179.

29. Yan SW, Asmah R. Comparison of total phenolic contents and antioxidant activities of turmeric leaf, pandan leaf and torch ginger flower. Int Food Res J 2010;17:417-23.

30. Sittiwet C. In vitro antimicrobial activity of Pluchea indica aqueous extract: The potential for urinary tract infection treatment. J Pharm Toxicol 2009;4:87-90.

31. Vu TT, Kim H, Tran VK, Dang QL, Nguyen HT, Kim H, et al. In vitro antibacterial activity of selected medicinal plants traditionally used in Vietnam against human pathogenic bacteria. BMC Comp Alternative Med 2016;16:32.

32. Nowotarska SW, Nowotarski KJ, Friedman M, Situ C. Effect of structure on the interactions between five natural antimicrobial compounds and phospholipids of bacterial cell membrane on model monolayers. Molecules 2014;19:7497-515. 